See discussions, stats, and author profiles for this publication at: https://www.researchgate.net/publication/324965902

Communication Strategies to Overcome Linguistic Barriers: A Snapshot of Indonesian Postgraduate Students as a Second Language Learner Living in Target Language Community

\section{Preprint · May 2018}

CITATIONS

0

1 author:

Yuliandri Yuliandri

Payakumbuh state polytechnic of agriculture

4 PUBLICATIONS 0 CITATIONS

SEE PROFILE
READS

6

Some of the authors of this publication are also working on these related projects:

The correlation between students' mispronunciation rate and listening test performance: a preliminary analysis of pronunciation and listening skills interrelatedness in the context of low-input rural-based college EFL learners View project

Rural-based english learners learning trajectory View project 


\title{
Communication Strategies to Overcome Linguistic Barriers: A Snapshot of Indonesian Postgraduate Students as a Second Language Learner Living in Target Language Community
}

\author{
Yuliandri \\ Politeknik Pertanian Negeri Payakumbuh \\ yuliandriss@gmail.com
}

\begin{abstract}
Being able to communicate effectively in English on both social and academic setting, is one of the biggest challenge faced by International students learning in English speaking countries like New Zealand. This challenge is inevitably relevant to students' from Indonesia, a country where English is not a second language. Extra effort is required since these International students must be able to learn and produce the language simultaneously in a very immediate context, shifting from EFL to ESL context. To be able to shift from these two different learning contexts, specific strategies are needed. The use of communication strategies is purposed to assist language learners in a target language community to in delivering and receiving messages in spoken communication. This research is aimed to: a) identify types of communication strategy used by Indonesian adult Postgraduate students; b) investigate how these communication strategies are learned and applied. The data is collected qualitatively through semi-structured interviews. The result of this study reveals that, the two respondents in general are using the same communication strategies: compensatory strategy in form of circumlocution; on the other hand, avoidance strategy is also applied as a last resort. Furthermore, this research also highlights learning strategies developed/learned by the respondents to upgrade their communication competence.
\end{abstract}

Keywords/index terms: Second language acquisition, ESL, Communication strategies, Indonesian English learners, Second language learners

\section{INTRODUCTION}

Speaking ability or oral competence has often been seen as a barrier that challenges the existence of a second language learner living in the target language community. Here, the writer would like to attribute this description to International students living in New Zealand as an English-speaking country. In this context, the challenge of becoming a second language learner is multiplied as the demand of using the learned second language increases, regardless of the stage and the success rate of the learning process itself. It is fascinating to see how these international students resume the role of both a language learner and, at the same time, an active language user to function within the society.

To be able to function effectively, a second language learner must be able to upgrade his/her communicative competence gradually. Every learner has their own preference to perform this task as a part of their learning. These ways or preferences are 
termed as style. Style is consistent preferences made by any individuals (Brown, 2007, p. 119). If this personalization is brought into educational context, it becomes learning styles (Brown, 2007, p. 119-120). Individuals with particular learning style will establish and apply certain learning strategies; 'complex procedures that individuals apply to tasks...' (O’Malley \& Chamot, 1990, p. 52, as cited in Mitchel \&Myles, 2004, p. 107).

A second language learner is assumed to apply a particular set of their preferred learning strategies. It might be in the form of metacognitive strategies, cognitive strategies, or socio-affective strategies (O’Malley \& Chamot in Mitchel \& Myles, 2004, p. 105-6). To use a target language in target language environment requires a language learner to actively develop their strategies, especially in spoken language where direct interaction with native speakers and fellow language learners occurs.

The strategies applied to social-mediating activity and interacting with others is the definition of socio-affective strategy (Brown, 2007, p. 134). In oral communication where everything is spontaneous and flexible, communication problems tend to occur within second language learners. To deal with the communication problems, a language learner has to employ particular communication strategies to be able to maintain the interaction.

A number of efforts had been done to investigate the use of learning strategies among ESL students. O' Malley et al (1985) had pioneered the investigation in this area. They investigated the use of learning strategies used by beginning and intermediate ESL students. One of their findings indicates the frequent use of metacognitive strategies by intermediate students if compared to the beginning level (O’Malley et al, 1985, p. 43).

Hong-Nam \& Leavell (2006) conducted a quantitative research on the use of learning strategies by 55 ESL students from different backgrounds participating in a college intensive English program. The research utilized the Strategy Inventory for Language Learning (SILL) as the method of data gathering. The Findings of this research show the use of learning strategy based on proficiency, gender and nationality. From proficiency viewpoint, compensation strategies are frequently used by intermediate level students. Beginner level students tend to use metacognitive strategies whereas advanced group use social strategies the most (2006, p. 405-6). From gender viewpoint, there is a slight difference in the use of affective strategies; female learners are reported to have a higher use of affective strategies (2006, p. 407). Based on the nationality, learners from Korea, Japan, and Other (small groups of learner from different countries) use metacognitive strategies while Chinese learners mostly prefer social strategies (2006, p. 408).

Nakatani (2006) also performed similar quantitative research, but his focus is on communicative tasks on EFL learners in Japan. The results of his research underlined factors for speaking and listening strategies. He utilizes the SILL and OCSI (Oral Communication Strategy Inventory) as the tools to collect data. He also correlates the data resulted from those two to data-collecting tools.

Most of researches done in investigating learning strategies are conducted quantitatively and in a big scale while research is relatively a small-scaled qualitative case study. 
Based on this interesting phenomenon, a mini research which was aimed to investigate particular communication strategies employed by different language learners to maintain their communication within the target language community was conducted. This research focuses mainly on socio-affective strategies and communication strategies in relation to speaking performance. However, it also highlights learning strategies (cognitive or metacognitive) applied by the learners in order to improve their speaking ability. This study addresses the following questions: A) What kind of communication strategies applied; before, during, and after speaking tasks by different learners to establish their interaction within target language community? B) What are the possible cognitive/metacognitive/socio-affective strategies employed by different learners to enhance their learning process in order to improve their speaking ability? These two questions were chosen since they represent the challenges faced by international students as second language learners in the target language community. They have to progress in their language acquisition and learning, and at the same time also become an active user of the learned language regardless of the difficulties in the learning process itself.

\section{METHODOLOGY}

This mini research is conducted qualitatively. Primary data is gathered from two different language learners as respondents. Both informants were interviewed separately in September 2012. The transcript of the interviews is the source of primary data. The secondary data is obtained from selected readings mentioned in reference list.

The interviews are semi-structured. The interviewer runs the interview with the help of a list of questions used a guide. There are rooms for improvisation on the question list if needed, and the interviewer can also prompt the interviewee to give some further explanation on some specific questions if necessary.

The respondents are two Indonesian postgraduate students studying at Massey University. One male respondent in his first year of Ph.D and the other one is female doing her second year of master's degree. The reason of choosing these particular informants is because they come from approximately the same background, similar age. They come from the same country, and before they start their study in New Zealand, they have attended specific language preparation course. The investigation is organized around the ideas of their similar backgrounds and what particular similarities and differences emerge in terms of their use of learning styles and communication strategies.

\section{FINDINGS}

\section{Overall strategies used on speaking or direct communication}

The strategies applied by these two different learners are categorized to time sequence in speaking;

\section{Pre-speech strategies}

I) Mental-translation process

Both informants admits that during certain stages in their English language they still experience the mental translation process; the translation of ideas from Bahasa Indonesia to English. 
II) Speech rehearsal

There are similar concessions made by both respondents that before communicating, especially in formal situation in their educational context, they tend to rehearse their speech before the actual interaction.

\section{On-speech strategies}

To overcome difficulties they faced during communication, both learners mainly apply two types of communication strategies (Dornyei's classification adapted on Brown, 2007, p. 138);

\section{I) Compensatory strategies}

The common compensatory strategies employed by both participants are circumlocution, the use of all purpose words and appeal for help from interlocutors.

II) Avoidance strategies

Both learners indicate similar response if they are put in the position when they cannot communicate their ideas even with the help of compensatory strategies. They tend to abandon the message and decide to move on to another point, or even giving up the idea of communication. It is not clear whether both respondents apply the topic avoidance strategies, but the female learners indicate this tendency.

\section{Post-speech strategies.}

Both respondents have the same impression of how the native speakers react to them during their interactions them. In both of the informants' opinion the kiwis are so welcoming and encouraging to them in any form of communication. However, these learners aware that during the interactions, whether it is formal or casual, they make mistakes and errors. They shared similar feeling of discomfort toward feedback and error correction to their spoken English.

\section{Learning strategies employed to improve speaking ability.}

From the findings, it can be highlighted that these two learners employ strategies that have been taught to them in a specific language course, it is then can be labeled as taught strategies. And later on, the respondents also reveal that in their journey as a language learner, they also develop their own personal strategies to overcome problems in direct communication.

\section{Learned strategies}

\section{Self-correction, fun learning.}

Male respondent reveal that during the language preparation program, his instructor asked him to record the sample of his speech, and then later listen to it. The sample is later re-recorded until the learner is satisfied with the result.

The female respondent once told by her instructor to utilize media like newspaper, magazines, TV news and even movies to help her improve her fluency in English, and she enjoys it, even until now, she sometimes still utilizes the strategy of using her time to watch news on the television to stimulate her spoken ability. 


\section{Self-developed/personal strategies}

One of strategies developed by male participant to his own use is to check correct words pronunciations by using Google translate. Another strategy he apply to intensify his communicative competence is by initiating more conversation, especially to native speakers.

The female respondent come up with a very interesting strategy, she practices her English with her children, since she is not too comfortable speaking with people that concerns too much about Grammar. She also a very motivated learner, her strategy is to forget all the difficulties in learning English, because she knew that if she could speak English, there will be numerous benefits for her.

\section{DISCUSSIONS}

During the interview, it is revealed that both learners experience various problems related to the use of spoken language. They refer to their earlier time after their first arrival in New Zealand. Both of them were experiencing difficulties in their effort to communicate their message trough spoken English. The male respondent specifically explained his experience during that early period. He mentioned at that stage, if he wants some assistance from the laboratory technician, he had to 'rewind' his utterances two or three times. The female respondent also made a similar remark, she emphasized that she was not really confident to speak, especially to native speakers.

These experiences had led both participants to give additional consideration to the use of spoken language. They became more aware of any possible breakdown in communication. This condition would later cause anxiety. Male respondent made a very interesting point when he explained that to him anxiety in speaking is not merely because his speaking ability, but it tends more to the cultural difference. He also claimed that this awareness had caused him to feel more comfortable speaking to fellow international students from Asian countries, because of similarities in cultural values. This point explains provide a very good example of John Schumann's concept of social distance (Brown, 2007, p. 196) between native culture and target language culture in second language learning. This respondent said that eventually, he shifted his perspectives to this. He said lately, he initiates more communication with native speakers.

The awareness to the importance of speaking ability to their role as international students make these participants understand the need of good communication strategies to overcome their lacking of knowledge in English in order to maintain communication as a part of their role in their communities.

\section{Overall strategies used on speaking or direct communication}

As mentioned earlier, these strategies are classified based on time sequence in a direct communication; pre-speech, on-speech, and post-speech strategies.

\section{Pre-speech strategies}

I) Mental-translation process

Shockingly, both participants admit that at some stages they still experience the process of idea translation from their first language to English inside their brain. Male 
respondent claimed that he still used to do this process when he speaks. In other words, he still thinks in Bahasa Indonesia and then translates it into English. Female respondent explained that she particularly experiences this process when she tries construct compound noun or phrases, due to different word order in Bahasa Indonesia if compared to English.

\section{II) Speech rehearsal}

Related to the idea of mental-translation process, male respondent noticed that in more prepared speech like in seminars or presentations, he used to practice what he is going to say. But he realizes that this strategy will not work on amore casual and informal situation.

\section{On-speech strategies}

This grouping is based on Dornyei's taxonomy of communication strategies (adapted in Brown, 2007, p. 138).

\section{I) Compensatory strategies}

Based on the feedback from both participants on how they overcome problems like losing specific vocabulary or lexical items during their oral communication, It can be seen that these two learners utilize three kinds of compensatory strategies; circumlocution, the use of all purposes words, and appeal for help. Male respondent explained that he tried to paraphrase his utterances if the interlocutors looked puzzled. Female respondent mentioned that she used to describe 'the lost word' by using all purpose words like 'the thing that', or circumlocutory clauses like 'the stuff that you...'. She even sometimes appealed for help from interlocutors by showing the object that she forgot about. The use of all purpose words like 'what do you call..' is considered frequent among these two learners.

\section{II) Avoidance strategies}

One obvious strategy that these two learners utilized is message abandonment. Both of them similarly explained that if breakdowns occur in the progress of communication, after two or three failures in efforts to compensate, they would drop the idea and move on to another topic. Male respondent said that this is purposed to maintain the effectiveness of the conversation, and it is probably better to look for the chance to try to articulate that particular idea later.

\section{Post-speech strategies}

Both respondents are aware of error and mistakes existence within their spoken English. They similarly agreed that after a speaking performance in formal or informal situation, there is an urgency of looking for input and feedback for improvement. But this type of constructive feedback is least expected in the form of language correction since both participants share the same attitude toward error correction.

Male learner claimed that he would rather prefer error correction from close friends, so that he would not feel ashamed and discouraged. This idea is related to selfesteem and language ego (see Brown, 2007, chapter 6).On the other hand it can also be seen as one example of his socio-affective strategies. 
Female learner is a learner who valued people who prefer not to criticize about her grammar in spoken English. She was not really comfortable talking to people who used to correct her grammar frequently. As a mean of her socio affective strategies she often seeks for constructive feedback from native speakers on her general performance in prepared speech like presentations.

\section{Strategies employed to improve spoken English}

\section{Learned strategies}

Male respondent mentioned the speech-recording strategy that reflects selfcorrection on oral performance. This is a pure example of cognitive strategies.

Throughout her language preparation course in Indonesia, the female participant was suggested by her instructors to utilize the use of written and electronic media as well as literature to add the enjoyment of her learning process. In other words, she is told to start language learning from something fun, something interesting. Unconsciously, this pattern had formed her metacognitive strategy to view language learning as something enjoyable.

\section{Self-developed/personalized strategies}

I) Pronunciation check on Google translate

This is an example of the cognitive strategies applied by male respondent as a continuation of self-correction process.

II) Intensive interaction with native speakers

The male learner gradually shifted his perceptions about native speakers. He found that in direct communication, native speakers are quite welcoming and encouraging. He emphasized that initiating more communication with native speakers may foster his knowledge and language development. This can be seen a manifestation his socio-affective strategies.

III) Language practice with children

Due to her discomfort of having error correction from random people, the female respondent established her 'safer' way to practice her spoken English with her children as fellow ESOL learners. She realized that children will make the least of attention to grammatical errors or mistakes. This particular strategy can also be categorized as her socio-affective strategy.

IV) Values of motivation

The female respondent also revealed one of her metacognitive strategies to overcome difficulties in English language learning in General. She said that "if you want to be a good speaker, don't worry too much about grammar", She said that thinking optimistically about the benefit of being able to speak well has maintained her motivation in learning. 


\section{CONCLUSION}

Through the findings in this mini research, it can be seen that both participants as second language learners are utilizing their strategies to overcome the difficulties in communication. Not only applying communication strategies as part of their strategic competence (Canale and Swain in Brown, 2007, p. 220), but also using their learned and self-developed metacognitive, cognitive and socio-affective strategies to improve their oral communication skill.

This small research has, indeed, pointed out to the correlation between personality, cognition, and socio-cultural influence in a language acquisition process and how these elements influence each other to create unique personalized learning styles of language learners.

\section{References:}

Brown, H.D. (2007). Principles of language learning and teaching ( $5^{\text {th }}$ Edition). San Fransisco: Longman Pearson.

Hong-Nam, K., \& Leavell, A. G. (2006). Language learning strategy use of ESL students in an intensive English learning context. System Linkoping, 34(3), 399-415.

Mitchell, R., \& Myles, F. (2004). Second language learning theories $\left(2^{\text {nd }}\right.$ Ed). New York: Oxford University Press.

Nakatani, Y. (2006). Developing an Oral Communication Strategy Inventory. The Modern Language Journal, 90(2), 151-168.

O’Malley, M. J., Chamot, A. U., Manzanares, G. S., Kupper, L., \& Russo, R. P. (1985). Learning strategies used by beginning and intermediate ESL students. Language learning, 35(1), 21-45. 